\title{
Feed Intake Patterns, Growth Performance, and Metabolic and Endocrine Traits in Calves Fed Unlimited Amounts of Colostrum and Milk by Automate, Starting in the Neonatal Period ${ }^{1}$
}

\author{
H. M. Hammon, G. Schiessler, A. Nussbaum, and J. W. Blum \\ Division of Animal Nutrition and Physiology, Institute of Animal Genetics, \\ Nutrition and Housing, Faculty of Veterinary Medicine, \\ University of Berne, \\ $\mathrm{CH}-3012$ Switzerland
}

\section{ABSTRACT}

Feed intake, growth performance, and metabolic and endocrine traits were studied in male calves fed unlimited (GrAL; $\mathrm{n}=7$ ) amounts of colostrum for $3 \mathrm{~d}$ after birth and mature milk up to d 28 and were compared with calves fed commonly recommended amounts of colostrum and milk (GrRS; $n=7$ ). Calves were fed by automates, and software was available to continuously register the time points and amounts of ingested feed up to $11 \mathrm{~d}$ of age. Body weight was measured on $\mathrm{d} 1$, $4,7,14,21$, and 28 , and blood samples were taken on $\mathrm{d} 1,2,3,7,14,21$, and 28 to measure several metabolites and hormones. Feed intake of calves fed GrAL increased from d 1 to 4, then remained stable and was always higher than for calves fed GrRS. Total visits (visits with and without milk intake) were higher for GrRS than GrAL, but visits with milk intake were comparable between groups and meal sizes per visit with milk intake were greater in GrAL than in GrRS. Body weight gain was greater in GrAL than in GrRS in wk 1, but not later. There were significant group differences in plasma concentrations of albumin (GrRS $>$ GrAL), nonesterified fatty acids (GrRS > GrAL), cholesterol (GrRS $>$ GrAL; d 28), insulin (GrAL > GrRS), and cortisol (GrRS > GrAL), but not of immunoglobin G, urea, glucose, triglycerides, growth hormone, and glucagon. In conclusion, calves fed ad libitum were capable of ingesting very large amounts of colostrum and milk, even during wh 1 of life, accompanied by a greater body weight gain in GrAL in the first week, whereas in GrRS, the high number of visits without feed intake indicate that these calves reached no repletion. Compared with calves provided restricted amounts of feed, calves with

Received March 6, 2002.

Accepted June 22, 2002

Corresponding author: H. M. Hammon; e-mail: harald.hammon@ itz.unibe.ch.

${ }^{1}$ Part of a combined thesis by A. Nussbaum and G. Schiessler for DVM, accepted June 2001 by the Faculty of Veterinary Medicine, University of Berne, Switzerland. free access to colostrum and milk were characterized by reduced plasma concentrations of nonesterified fatty acids and by a transiently enhanced insulin and reduced cortisol status.

(Key words: feeding intensity, growth performance, metabolites and hormones, neonatal calf)

Abbreviation key: $\mathbf{C}=$ colostrum; $\mathbf{C F}=$ crude fat; $\mathbf{G E}$ = gross energy, $\mathbf{G H}=$ growth hormone $; \mathbf{G r A L}=$ calves fed ad libitum; GRF = growth hormone-releasing factor; GrRS = calves fed commonly recommended amounts; IgG = immunoglobin G; $\mathbf{M P}=$ milk powder; $\mathbf{N F E}=$ nitrogen-free extracts; $\mathbf{T}_{\mathbf{3}}=3,5,3^{\prime}$-triiodothyronine; $\mathbf{T}_{\mathbf{4}}$ $=$ thyroxine; $\mathbf{T R H}=$ thyrotropin-releasing hormone.

\section{INTRODUCTION}

Neonatal calves in conventional dairy farms are separated immediately after birth from their dams and receive limited amounts of colostrum (C) and milk, usually twice daily by bucket. In contrast, suckling calves reared with their dams have free access to $\mathrm{C}$ and milk and ingest feed from their dams four to eight times daily (Meyer and Kamphues, 1990; Odde et al., 1985; Riese et al., 1977). In suckling calves, postnatal growth rates were greater than is usually seen in calves raised with limited feed intake (Egli and Blum, 1998). A reason for this might be the greater amounts of ingested $\mathrm{C}$ and milk than is usually found with recommended portions in conventional dairy farms (Egger and Kessler, 1994; Kirchgessner, 1996). However, feed intake is difficult to evaluate in cow-calf systems, and the measurements of feed intake using the weigh-suckle-weigh method (Odde et al., 1985) may negatively interfere with the cow and calf.

Furthermore, nonnutritive sucking often occurs in common breeding systems when calves are given limited access to food. Nonnutritive sucking depends on amounts and time of milk intake, and is reduced when feeding rates are high and sucking time is prolonged (Bolliger, 1998; Graf et al., 1989). 
Based on the circumstances mentioned above, calves were fed unlimited amounts of $\mathrm{C}$ and milk by an automatic feeder, starting in the neonatal period. Therefore, calves could choose the amounts and time of feed intake on their own, and amounts and time of feed intake were measured by the automate. Feed intake, growth performance, and metabolic and endocrine changes in these calves were compared with calves fed $\mathrm{C}$ and milk in amounts commonly recommended in Swiss dairy farms (Egger and Kessler, 1994). To avoid effects of the feeding frequency, this group was also fed by an automatic feeder. We have tested the hypothesis that calves receiving unlimited amounts of $\mathrm{C}$ and milk are characterized by improved nutritional status and by metabolic and endocrine changes that express anabolic metabolism and are followed by enhanced growth performance. Major emphasis was placed on feed intake patterns and was associated with metabolic and endocrine traits during the first 2 wk of life.

\section{MATERIALS AND METHODS}

\section{Animals, Husbandry, Feeding, and Experimental Procedures}

The experimental procedures followed the Swiss law on animal protection and were approved by the Committee for the Permission of Animal Experimentation of the Canton of Freiburg (Granges-Paccot, Switzerland).

Calves were born between November 1999 and February 2000 after normal lengths of pregnancy and with normal parturitions. They were obtained immediately after birth, weighed, and held in loose housing systems on straw litter for $28 \mathrm{~d}$.

Two treatment groups were created: 1) calves fed unlimited amounts (GrAL) of C for $3 \mathrm{~d}$ after birth and mature milk up to d 28 and, 2) calves fed commonly recommended amounts (GrRS) of $\mathrm{C}$ and milk. Each treatment group consisted of seven calves (four Simmental $\times$ Red Holstein, two Braunvieh $\times$ Brown Swiss, and one Holstein Friesian in GrRS, and six Simmental $\times$ Red Holstein and one Braunvieh $\times$ Brown Swiss in GrAL). Calves of GrRS and GrAL received their first meal at $3.4 \pm 0.7$ and $3.0 \pm 0.7 \mathrm{~h}$ after birth, respectively. The GrRS calves received restricted amounts of $\mathrm{C}$ and milk, whereas in GrAL, amounts of $\mathrm{C}$ and milk were much more than calves were able to drink (Table 1). On d 1 postpartum, calves of both groups were fed six times using bottles equipped with a nipple. Ingested amounts were $0.5 \mathrm{~L}$ per meal in GrRS and 0.5 to $1 \mathrm{~L}$ per meal in GrAL. From d 2 and thereafter, calves were fed C or milk by an automate (Stand-Alone II, Frster, Engen, Germany; program: Kalbmanager 4.2). Software was available to continuously register the time points and amounts of ingested feed (Instituts- programm 1.0, Förster, Engen, Germany) up to the age of $11 \mathrm{~d}$. Afterwards, calves had to be fed by a nonprogrammable automate. Feeding program on d 2 started at $24 \mathrm{~h}$ and on $\mathrm{d} 3$ at $48 \mathrm{~h}$ after the first postnatal meal. From d 4 and thereafter, the feeding program started daily at $0800 \mathrm{~h}$. The minimal and maximal meal sizes were 0.5 and $1.5 \mathrm{~L}$, respectively. As calves were able to choose the frequency of feed intake, it was possible for calves to enhance the ingested amounts per visit (up $1.5 \mathrm{~L}$ ) by reducing the frequency of visits. No concentrates were offered, but hay was fed during the 28$\mathrm{d}$ experimental period. The feeding plan is shown in Table 1.

Calves received $\mathrm{C}$ during the first $3 \mathrm{~d}$, milk powder (MP) from d 4 to 14, and milk from the milk pool (derived from 60 to 70 cows) of the Research Station from d 15 to 28 . This feeding schedule was chosen to imitate the natural situation of calves after birth. As the total number of calves was small, MP was used instead of milk for the first $14 \mathrm{~d}$. Colostrum, from first milkings after parturition, was purchased as powder (Col-o-Dan, Damino, Gesten, Denmark, and Hokovit, Buetzberg, Switzerland), and each kilogram of DM contained 23.6 MJ of gross energy (GE), $450 \mathrm{~g}$ of $\mathrm{CP}, 250 \mathrm{~g}$ of crude fat (CF), $200 \mathrm{~g}$ of nitrogen-free extract (NFE; mainly lactose), $50 \mathrm{~g}$ of crude ash, and $106 \mathrm{~g}$ of immunoglobin G (IgG). Milk powder (Vollmilchpulver Sprh 26\%; Emmi AG, Dagmersellen, Switzerland) contained (per kilogram of DM) $22.5 \mathrm{MJ}$ of GE, $264 \mathrm{~g}$ of CP, $265 \mathrm{~g}$ of $\mathrm{CF}, 380 \mathrm{~g}$ of NFE (mainly lactose), and $60 \mathrm{~g}$ of crude ash. IgG content was below the detection limit. The pooled milk contained $22.9 \mathrm{MJ}$ of GE, $274 \mathrm{~g}$ of $\mathrm{CP}, 273$ $\mathrm{g}$ of CF, $397 \mathrm{~g}$ of NFE (mainly lactose), $56 \mathrm{~g}$ of crude ash, and $0.1 \mathrm{~g}$ of IgG per $\mathrm{kg}$ of DM.

Before first feed intake, calves were subcutaneously injected with $2 \mathrm{~g}$ of a bovine colostral Ig preparation (Gammaserin, Dr. Graeub AG, Berne, Switzerland) and with $50 \mathrm{mg}$ of vitamin $\mathrm{E}$ and $10 \mathrm{mg}$ of selenium (Selen-E Vetag, Veterinaria AG, Zürich, Switzerland). The navel was disinfected with an iodine solution (Betadine, Provet AG, Lyssach, Switzerland). Between d 2 and 4, calves were prophylactically subcutaneously injected with antibiotics $(100 \mathrm{mg}$ of penicillin and $100 \mathrm{mg}$ of streptomycin $/ 10 \mathrm{~kg}$ of BW; Pen-Strep 20/20 Veterinaria AG, Zürich, Switzerland; $25 \mathrm{mg}$ of Enrofloxacin $/ 10 \mathrm{~kg}$ of BW; Baytril 5\%; Bayer AG, Leverkusen, Germany). On d 3, calves were prophylactically, subcutaneously injected with $50 \mathrm{mg}$ of iron/10 kg BW (Ferriphor 10\%; Lohmann Animal Health GmbH, Cuxhaven, Germany).

\section{Growth Performance and Health Status}

Body weight was measured on d $1,4,7,14,21$, and 28 . Health status was evaluated daily during the first 
Table 1. Pre-programmed automate settings and DM contents of colostrums, milk powder, and milk.

\begin{tabular}{|c|c|c|c|c|c|c|c|c|c|}
\hline \multirow[b]{3}{*}{ Trait } & \multirow{2}{*}{\multicolumn{3}{|c|}{$\begin{array}{c}\text { Colostrum } \\
\text { Day }\end{array}$}} & \multirow{2}{*}{\multicolumn{3}{|c|}{$\begin{array}{c}\text { Milk powder } \\
\text { Day }\end{array}$}} & \multirow{2}{*}{\multicolumn{3}{|c|}{$\begin{array}{c}\text { Milk } \\
\text { Day }\end{array}$}} \\
\hline & & & & & & & & & \\
\hline & $1^{1}$ & 2 & 3 & $4-7$ & $8-11$ & $12-14$ & $60-70$ & $70-80$ & $80-90$ \\
\hline $\begin{array}{l}\mathrm{DM}, \mathrm{g} / \mathrm{kg} \text { milk } \\
\text { Available amount of milk, } \mathrm{L}\end{array}$ & $250 / 200^{3}$ & 150 & 120 & 120 & 120 & 120 & 130 & 130 & 130 \\
\hline $\begin{array}{l}\text { Avaulabole amount of milk, } \mathrm{L} \\
\text { GrRS }\end{array}$ & \multicolumn{9}{|c|}{ Available amount of milk, L } \\
\hline GrAL & 6 & 12 & 12 & 24 & 24 & 24 & 24 & 24 & 24 \\
\hline \multicolumn{10}{|l|}{ Pre-programmed visits/d ${ }^{4}$} \\
\hline GrRS & 6 & 8 & 10 & 10 & 12 & 14 & 14 & 14 & 14 \\
\hline GrAL & 6 & 24 & 24 & 24 & 24 & 24 & 24 & 24 & 24 \\
\hline
\end{tabular}

${ }^{1}$ Calves were fed by bucket.

${ }^{2} \mathrm{DM}$ of colostrums and milk powder contained $40 \mathrm{~g}$ and $50 \mathrm{~g}$ water/kg respectively.

${ }^{3} 250 \mathrm{~g}$ colostrums/kg from 0 to $9 \mathrm{~h}$ in GrRS and from 0 to $12 \mathrm{~h}$ in GrAL, and $200 \mathrm{~g}$ colostrums/kg from 9 to 18 in GrRS and from 12 to $24 \mathrm{~h}$ in GrAL after start of the experiment.

${ }^{4}$ Intake was divided into several portions per day, minimal and maximal amounts were $0.5 \mathrm{~L}$ and $1.5 \mathrm{~L}$ per portion, respectively. The automatic feeder calculated the disposable amount for each visit. For GrRS time allowed for access to the automate was $16 \mathrm{~h}$ to avoid too small portions per visits. However, calves were allowed to drink non-retrieved milk after the 16 -h period.

week and on d 14, 21, and 28. Rectal temperature, heart rate, and respiratory rate were measured on those days. Clinical traits were evaluated as follows: behavior (attentive or weak), nasal discharge (none or present), navel appearance (normal or inflamed), and fecal consistency (normal, thin, watery, bloody).

\section{Blood Samples}

Blood samples were taken from the jugular vein with evacuated tubes on d 1, 2, 3, 14, 21, and 28. On d 6 , catheters were inserted into the jugular vein for blood sampling on $\mathrm{d} 7$ and 8. Tubes containing dipotassiumEDTA $(1.8 \mathrm{mg} / \mathrm{mL}$ of blood) were used to determine concentrations of total protein, albumin, urea, creatinine, NEFA, triglycerides, cholesterol, glucose, insulin, glucagon, growth hormone (GH), IGF-I, 3,5,3'-triiodothyronine $\left(\mathbf{T}_{3}\right)$, and thyroxine $\left(\mathbf{T}_{4}\right)$ before the start of feeding on $\mathrm{d} 1,2,3,7,14,21$, and 28 . L-lactate was determined in blood samples before start of feed intake on $\mathrm{d} 1,2,3,7,14,21$, and 28 using evacuated tubes containing dipotassium-EDTA $(1.8 \mathrm{mg} / \mathrm{mL}$ of blood $)$ and sodium fluoride ( $3 \mathrm{mg} / \mathrm{mL}$ of blood). Tubes without anticoagulants were used to measure IgG in serum on $d 1$, $2,3,7,14,21$, and 28 . The GH secretory pattern was furthermore evaluated in blood samples (tubes containing dipotassium-EDTA) on $\mathrm{d} 7$, taken before $(0 \mathrm{~h})$ and every $20 \mathrm{~min}$ after the start of feeding for $8 \mathrm{~h}$. In addition, on $\mathrm{d} 8$, the concentration of GH was measured in blood samples taken before $(-20 \mathrm{~min}$ and $0 \mathrm{~h})$ and after $(10,20,30,40,50,60,80,100,120,140,170,200$, 240 , and $300 \mathrm{~min}$ ) the start of feed intake, and T3 and $\mathrm{T} 4$ were measured in blood samples taken before (-20 min and $0 \mathrm{~h}$ ) and after the start of feed intake (at 30, $60,120,170,240$, and $300 \mathrm{~min}$ ) and the injection of the GH-releasing factor (GRF) analog (GRF-1-29; $10 \mu \mathrm{L} /$ $\mathrm{kg}$ BW from Pharmacia-Upjohn, Kalamazoo, MI) and the thyrotropin-releasing hormone (TRH, $20 \mu \mathrm{L} / \mathrm{kg}$ of BW; Calbiochem, San Diego, CA, USA).

Collected tubes containing anticoagulants were immediately put on ice until centrifugation. Tubes without anticoagulants were stored at room temperature for 15 to $30 \mathrm{~min}$ before centrifugation. Tubes were centrifuged at $1000 \times \mathrm{g}$ for $20 \mathrm{~min}$ at $4^{\circ} \mathrm{C}$ within 30 to $60 \mathrm{~min}$ after collection. Supernatants were portioned into aliquots and stored at $-20^{\circ} \mathrm{C}$ until analysis. Whole blood was used for the determination of the hematocrit before the start of feed intake on $\mathrm{d} 1,3$, and 28.

\section{Laboratory Analyses}

Blood analyses. Plasma concentrations of total protein, urea, creatinine, glucose, triglycerides, and cholesterol were measured using kits (Hoffmann-La Roche, Basel, Switzerland; \#0736783, \#0736856, \#0736678, \#0736716, \#0736791, and \#0736643, respectively). Albumin and lactate were measured with Bio Mérieux kits (Bio Mérieux, Marcy l'Etoile, France; \#61051 and \#61192, respectively), and NEFA was measured using a Wako Chemicals kit (Wako Chemicals, Neuss, Germany; \#994-75409). An automatic analyzer (Cobas Mira Plus, Roche, Basel, Switzerland) was used to analyze these traits. The IgG concentration in serum was determined by ELISA (Erhard et al., 1995). Concentrations of insulin, glucagon, cortisol, GH, IGF-I, $\mathrm{T}_{3}$, and $\mathrm{T}_{4}$ were measured by radioimmunoassay as described 
by Egli and Blum (1998). To determine the hematocrit, a microhematocrit centrifuge was used.

Milk analyses. Contents of $\mathrm{CP}, \mathrm{CF}$, and crude ash in $\mathrm{C}$ and MP were provided by the manufacturers. Chemical analysis of milk was performed in the routine laboratory of the Swiss Federal Research Station for Animal Production (Posieux, Switzerland), a certified reference laboratory for animal feeds analysis. Methods were based on Weender analysis. Amounts of DM (ME10303.710) were measured gravimetrically at $105^{\circ} \mathrm{C}$ for $3 \mathrm{~h}(\mathrm{CV}<1 \%)$. Inorganic matter (crude ash; ME104030.710) was measured gravimetrically after combustion at $550^{\circ} \mathrm{C}$ for $4 \mathrm{~h}(\mathrm{CV}<2 \%)$. The $\mathrm{CF}$ concentration (ME113020.710) was measured by Soxhlet fat extraction $(\mathrm{CV}<2.5 \%)$. The $\mathrm{CP}$ concentration (ME150020.710) was measured according to Kjeldahl by photometrical determination. The NFE in milk and the GE contents in $\mathrm{C}, \mathrm{MP}$, and milk (based on energy equivalents of $36.6,17.0$, and $24.2 \mathrm{MJ} / \mathrm{kg}$ of fat, $\mathrm{NFE}$, and $\mathrm{CP}$, respectively) were calculated. Colostrum, MP, and milk were defatted by centrifugation at $800 \times \mathrm{g}$ for $15 \mathrm{~min}$ at $4^{\circ} \mathrm{C}$, and skim milk was centrifuged at 10,000 $\times \mathrm{g}$ for $15 \mathrm{~min}$ before the determination of IgG as described for serum.

\section{Statistical Analyses}

Values of hematocrit, metabolic, and endocrine traits, as well as growth performance data, are expressed as means \pm standard error of the means. For time and treatment differences, concentrations of metabolites

Table 2. Body weight, BW gain, DMI, ADG, and feeding efficiency in newborn calves fed either restricted (GrRS; $\mathrm{n}=7$ ) or unlimited (GrAL; $\mathrm{n}=7$ ) amounts of colostrums and milk by automate.

\begin{tabular}{|c|c|c|c|}
\hline Trait & GrRS & GrAL & $\mathrm{SE}$ \\
\hline \multicolumn{4}{|l|}{ BW } \\
\hline at birth, kg & 46.9 & 46.6 & 1.7 \\
\hline d 7 & 50.1 & 52.8 & 1.3 \\
\hline d 28 & 66.1 & 70 & 1.7 \\
\hline \multicolumn{4}{|l|}{$\mathrm{BW}$ gain, $\mathrm{kg}$} \\
\hline d 1 to 7 & $3.3^{\mathrm{b}, *}$ & $6.1^{\mathrm{a}, *}$ & 0.8 \\
\hline d 1 to 28 & $19.2^{*}$ & $22.6^{*}$ & 2.1 \\
\hline \multicolumn{4}{|l|}{ DMI, kg } \\
\hline d 1 to 7 & $3.7^{\mathrm{b}}$ & $6.3^{\mathrm{a}}$ & 0.3 \\
\hline d 1 to 28 & $21.6^{b}$ & $32.9^{\mathrm{a}}$ & 0.9 \\
\hline \multicolumn{4}{|l|}{$\mathrm{ADG}$} \\
\hline d 1 to 7 & 0.55 & 1.02 & 0.14 \\
\hline 1 to 28 & 0.71 & 0.84 & 0.08 \\
\hline \multicolumn{4}{|c|}{ Feeding efficiency ${ }^{1}$} \\
\hline d 1 to 7 & 0.9 & 0.99 & 0.19 \\
\hline d 1 to 28 & 0.88 & 0.69 & 0.07 \\
\hline
\end{tabular}

and hormones were evaluated using the RANDOM and REPEATED methods of the MIXED procedure of SAS (SAS, 1994). Concentrations of GH and insulin were logarithmically transformed. Treatment (i.e., different feed intake) and time were used as fixed effects and the individual calves were used as random effects. For analyses of differences in time pattern between groups, the interaction (treatment $\times$ time) was included in the model. Treatment differences at specific time points were localized by Bonferroni $t$-test $(P<0.05)$.

Episodic secretion of GH on d 7 (mean concentrations, basal concentrations, peak amplitudes, and peak frequencies) were analyzed according to Merriam and Wachter (1982). Group differences were analysed by Student's $t$-test (SAS,1994).

Changes in BW gain and BW gain per milk intake were determined by paired $t$-test (SAS, 1994). Group differences of growth performance data were evaluated by Student's $t$-test. Differences in frequencies of visits and DMI were evaluated by means of Wilcoxon's twosample test (SAS 1994) because of the lack of normal data distribution.

\section{RESULTS}

\section{Growth Performance, Feed Intake, and Health Status}

Body weights before first feed intake (Table 2) in GrRS and GrAL were similar and increased $(P<0.001)$ in both groups up to $d 28$. The BW gain for wk 1 was greater $(P<0.05)$ in GrAL than in GrRS, but there were no group differences over the 28 -d period. The DMI was greater $(P<0.05)$ during wk 1 and during the 28-d period in GrAL than in GrRS. In GrAL, DMI increased to $1.3 \pm 0.02 \mathrm{~kg}$ of $\mathrm{DM} / \mathrm{d}$ on $\mathrm{d} 4$ and remained constant to d 28 (data not shown), whereas in GrRS, the DMI increased according to the feeding plan. The ADG and feeding efficiency did not differ between groups during wk 1 of life or during the 28-d observation period.

The frequency of total visits (i.e., visits at the automatic feeder with and without feed intake) and of successful visits (i.e., visits with milk intake) was measured between $d 2$ and 11 (Figure 1). During the 10-d observation period, the frequency of total visits was higher $(P<0.05)$ in GrRS than in GrAL. The frequency of successful visits was higher $(P<0.05)$ on $d 8$ in GrRS than in GrAL. Mean milk intake per successful visit (from $d 2$ to 11$)$ was higher $(P<0.05)$ in GrAL than GrRS $(1.0 \times 0.13$ and $0.6 \times 0.04 \mathrm{~L} /$ successful visit in GrAL and GrRS, respectively).

DMI and total and successful visits on d 4 to 6 as well as on d 9 to 11 were divided into six intervals of $4 \mathrm{~h}$, beginning at $0800 \mathrm{~h}$ (Figure $2 \mathrm{~A}$ to $2 \mathrm{C}$ ). Due to 

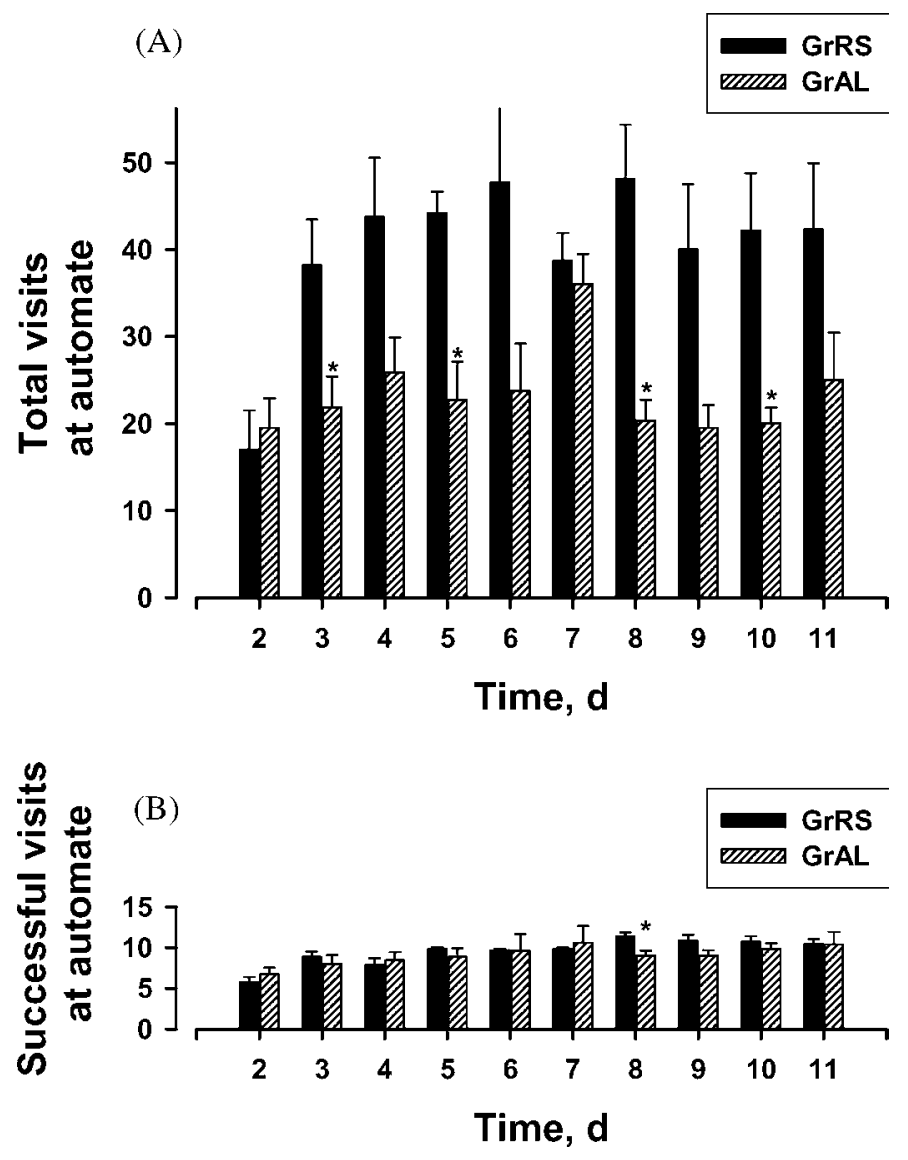

Figure 1. Total visits (i.e., visits with and without milk intake) to the automate from d 2 to 11 (A) and successful visits (i.e., visits with milk intake) at the automate from d 2 to 11 (B). Calves were fed either restricted (GrRS, solid) or unlimited (GrAL, striped) amounts of colostrum and milk. *Means are significantly different $(P<0.05)$ between groups.

restricted feeding in GrRS, DMI was mainly limited to the 18-h feeding period. However, when calves of GrRS did not drink the assigned milk left, they were allowed to drink this milk after the 18 -h period. The DMI in GrAL was greater $(P<0.05)$ than in GrRS on $d 4$ to 6 from 1600 to $2000 \mathrm{~h}$ and from 0400 to 0800 , and on $\mathrm{d}$ 9 to 11 from 2400 to $0800 \mathrm{~h}$.

The frequency of total visits (Figure 2B) was higher $(P<0.05)$ in GrRS than GrAL from 1200 to $2400 \mathrm{~h}$ on d 4 to d 6, and from 0800 to $2000 \mathrm{~h}$ and from 2400 to $0400 \mathrm{~h}$ on $\mathrm{d} 9$ to 11 .

Successful visits (Figure 2C) in GrRS were rarely observed after the 18-h feeding period due to restricted feeding. Successful visits in GrRS were higher $(P<0.05)$ than in GrAL from 1200 to $1600 \mathrm{~h}$ and from 2000 to $2400 \mathrm{~h}$ on $\mathrm{d} 4$ to 6 and from 0800 to $1200 \mathrm{~h}$ on $\mathrm{d} 9$ to 11 , but were higher $(P<0.05)$ in GrAL than in GrRS from 0400 to $0800 \mathrm{~h}$.

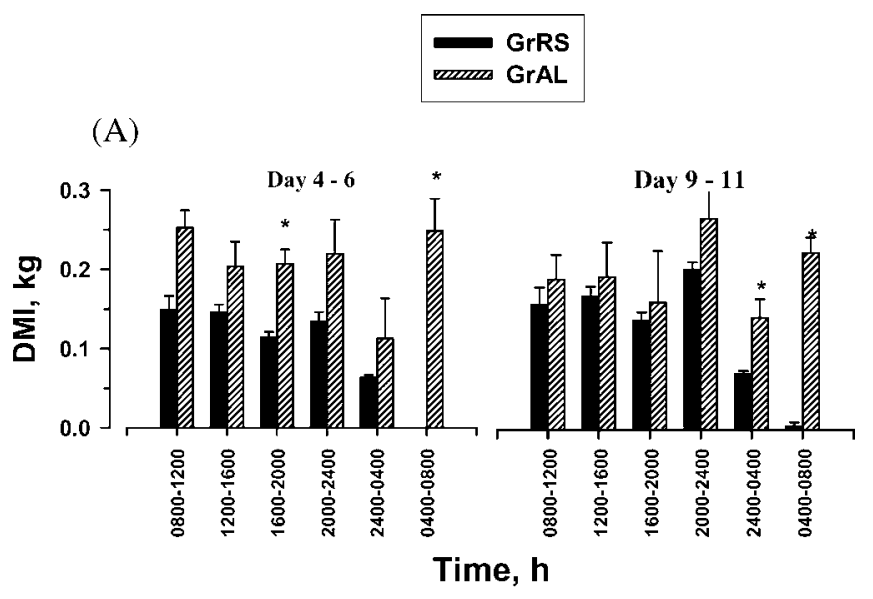

(B)
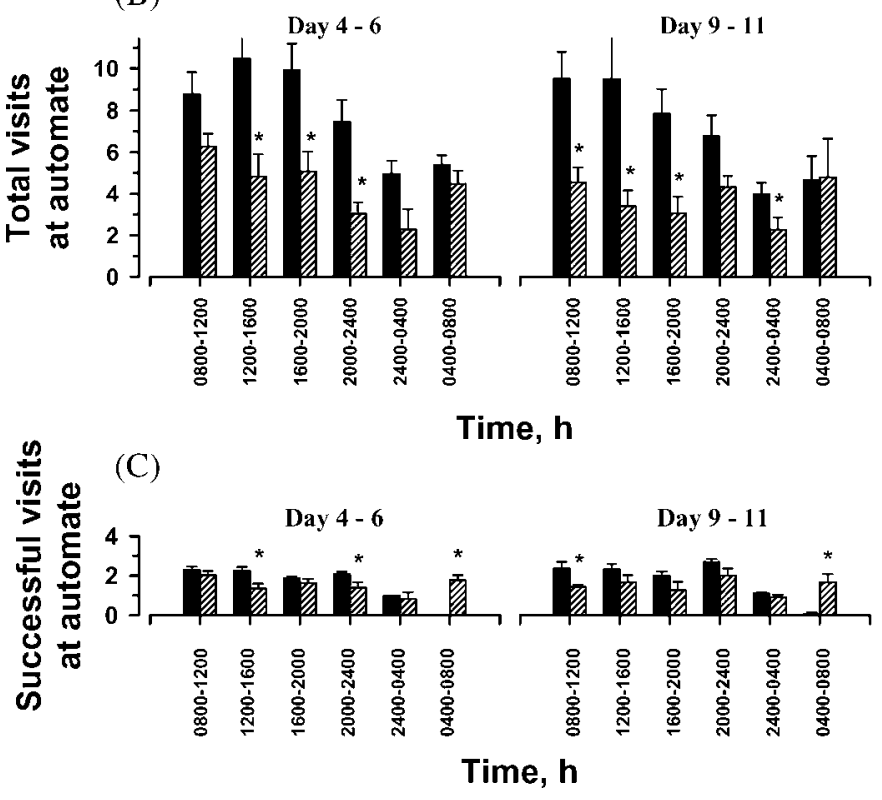

Figure 2. DMI (A), total visits (B), and successful visits (C) from d 4 to 6 and d 9 to 11 were summarized and divided into six intervals of $4 \mathrm{~h}$ each beginning at $0800 \mathrm{~h}$. Calves were fed either restricted (GrRS, solid) or unlimited (GrAL, striped) amounts of colostrum and milk. Feed was available for $18 \mathrm{~h}$ (GrRS) or $24 \mathrm{~h}$ (GrAL), beginning daily at $0800 \mathrm{~h} . *$, Means are significantly different $(P<0.05)$ between groups.

Calves were generally healthy and health status was similar in both groups. However, loose feces were apparent on $\mathrm{d} 7$ from one GrRS calf and in two GrAL calves, on $\mathrm{d} 14$ in two calves of each group, and on d 21 in two GrRS calves.

\section{Blood Plasma Metabolite Concentrations}

Hematocrit decreased $(P<0.001)$ from birth to $\mathrm{d} 28$ in both groups $(0.41 \pm 0.03$ and $0.38 \pm 0.02$ on $\mathrm{d} 1 ; 0.29$ \pm 0.02 and $0.29 \pm 0.01$ on $d 7$; and $0.26 \pm 0.02$ and 0.23 
Table 3. Basal plasma concentrations of metabolites in neonatal calves fed either restricted $(\mathrm{GrRS} ; \mathrm{n}=7)$ or unlimited $(\mathrm{GrAL} ; \mathrm{n}=7)$ amounts of colostrum and milk by an automate.

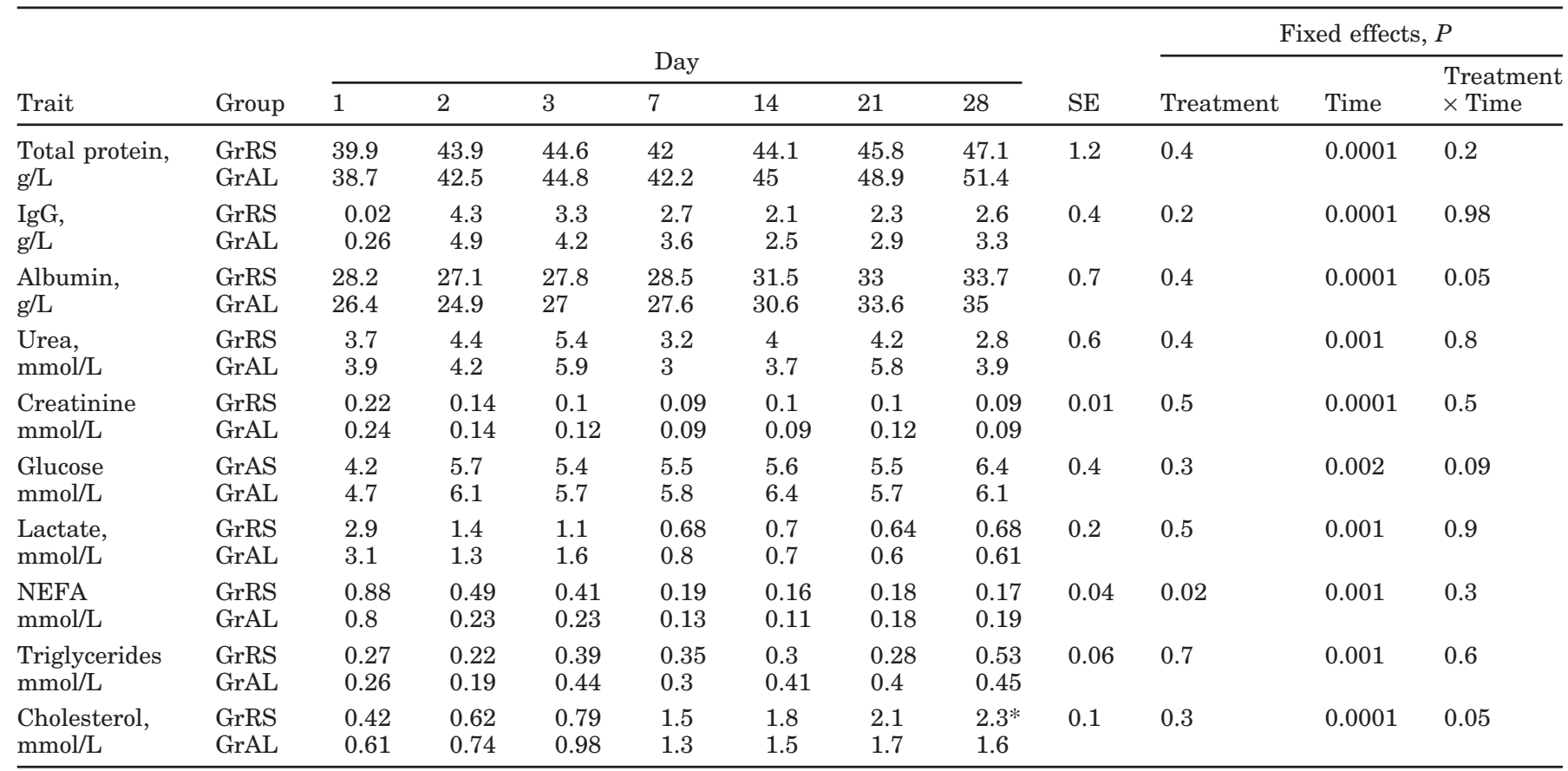

*Means are significantly $(\mathrm{P}<0.05)$ different between groups.

\pm 0.01 on $d 28$ in GrRS and GrAL, respectively). There were no significant group differences.

Total protein and IgG concentrations (Table 3) increased $(P<0.0001)$ in both groups during the experimental period. Albumin concentrations (Table 3) decreased $(P<0.01)$ in both groups from $\mathrm{d} 1$ to $\mathrm{d} 2$, and then increased $(P<0.01)$ up to $\mathrm{d} 28$, and the treatment $\times$ time interaction during the 28 -d period was significant. Urea concentrations (Table 3) changed over time $(P<$ 0.0001) during the experimental period, but there were no group differences. Creatinine concentrations (Table $3)$ decreased $(P<0.001)$ from birth up to $\mathrm{d} 7$ in both groups and were low up to $d 28$, but there were no significant group differences.

Glucose concentrations (Table 3$)$ increased $(P<0.001)$ in both groups up to $d 28$, whereas lactate concentrations (Table 3$)$ decreased $(P<0.001)$ continuously from birth to $\mathrm{d} 7$ in both groups and then remained at low concentrations until $d 28$. Plasma glucose and lactate concentrations were not significantly different between groups.

NEFA concentrations (Table 3) were high at birth and decreased $(P<0.001)$ with time. Concentrations were higher $(P<0.05)$ in GrRS than in GrAL during the 28-d period. Triglyceride concentrations (Table 3) changed with time $(P<0.001)$, but there were no significant group differences. Cholesterol concentrations (Table 3$)$ increased $(P<0.001)$ from birth to d 28 in both groups. The treatment $\times$ time interaction during the 28-d period was significant, and concentrations of cholesterol on d 28 were higher $(P<0.01)$ in GrRS than in GrAL.

\section{Blood Plasma Hormone Concentrations}

Basal insulin concentrations (Table 4) increased $(P$ $<0.05$ ) in both groups after birth up to d 28. Insulin concentrations were higher $(P<0.05)$ in GrAL than in GrRS. Glucagon concentrations (Table 4) changed with time $(P<0.0001)$, but there were no significant group differences. Plasma cortisol concentrations (Table 4) decreased $(P<0.0001)$ after birth in both groups. Cortisol concentrations were higher $(P<0.01)$ in GrRS than in GrAL.

Basal plasma GH concentrations (Table 4) changed with time $(P<0.001)$, but there were no significant group differences over the experimental period of $28 \mathrm{~d}$. During the 8-h period on $\mathrm{d} 7$, mean concentrations were $20.2 \pm 3.2 \mu \mathrm{g} / \mathrm{L}$ in $\mathrm{GrRS}$ and $23.9 \pm 5.1 \mu \mathrm{g} / \mathrm{L}$ in $\mathrm{GrAL}$; basal concentrations were $8.4 \pm 2.4 \mu \mathrm{g} / \mathrm{L}$ in GrRS and $14.4 \times 4.3 \mu \mathrm{g} / \mathrm{L}$ in $\mathrm{GrAL}$; peak amplitudes were $52.5 \pm$ $6.6 \mu \mathrm{g} / \mathrm{L}$ in GrRS and $48.8 \pm 12.6 \mu \mathrm{g} / \mathrm{L}$ in $\mathrm{GrAL}$; and peak frequencies were $0.29 \pm 0.02 \mathrm{~h}^{-1}$ in GrRS and 0.31 $\pm 0.03 \mathrm{~h}^{-1}$ in GrAL, but there were no significant group differences. On d 8, GH concentrations were $15 \pm 4 \mu \mathrm{g} /$ $\mathrm{L}$ before injection of GRF in both groups and increased 
Table 4. Plasma concentrations of hormones in neonatal calves fed by an automate either restricted amounts of colostrum and milk (GrRS; $\mathrm{n}=7$ ) or fed unlimited amounts of colostrum and milk (GrAL; $\mathrm{n}=7$ ).

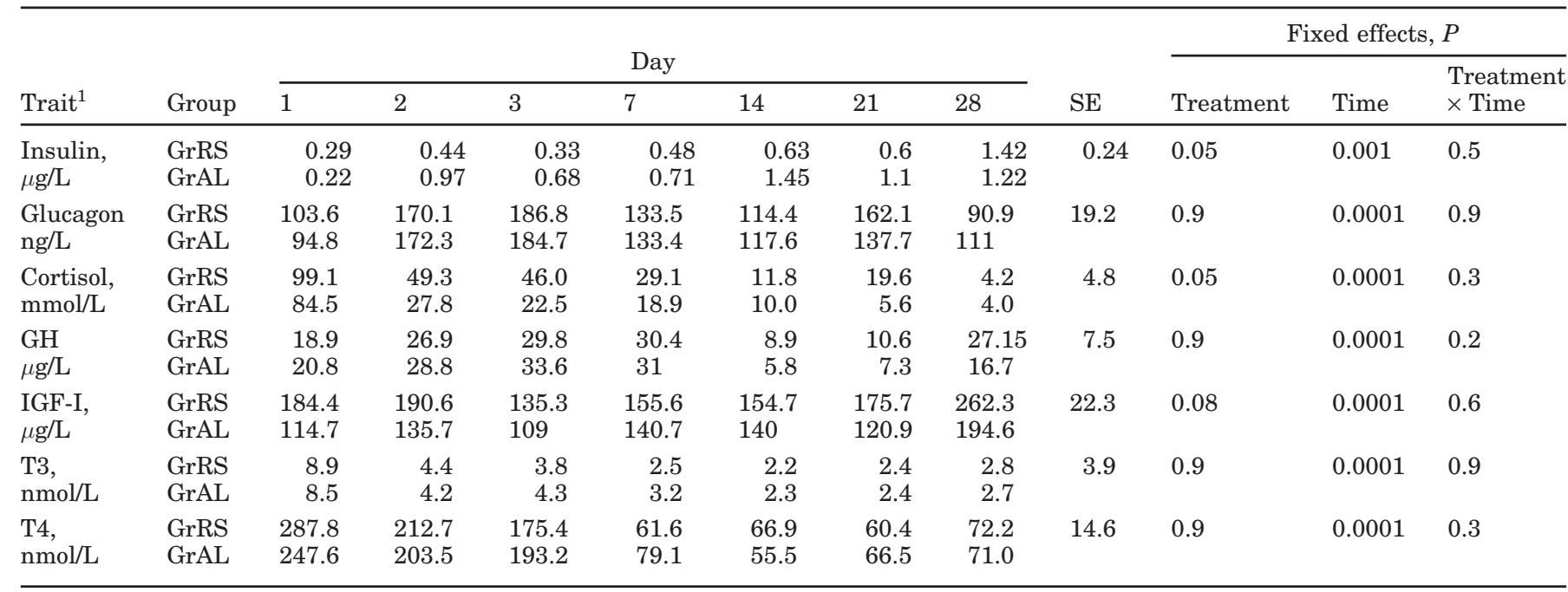

${ }^{1} \mathrm{GH}=$ growth hormone, $\mathrm{T}_{3}=3,5,5^{\prime}$-triiodothyronine, $\mathrm{T}_{4}=$ throxine.

$(P<0.001)$ in both groups to highest concentrations $(209 \pm 72 \mu \mathrm{g} / \mathrm{L})$ at $10 \mathrm{~min}$ after GRF injection. GH concentration then decreased $(P<0.001)$ to basal levels at $140 \mathrm{~min}$ in GrAL and at $200 \mathrm{~min}$ in GrRS. There were no significant group differences.

Concentrations of IGF-I (Table 4) changed with time $(P<0.001)$ in both groups and tended to be higher $(P$ $<0.1$ ) in GrRS than in GrAL during the 28-d period.

Concentrations of $\mathrm{T}_{3}$ and $\mathrm{T}_{4}$ (Table 4 ) in both groups decreased $(P<0.001)$ from birth to $\mathrm{d} 7$, and then were low up to $d 28$. There were no significant group differences. On d 8, mean plasma $\mathrm{T}_{3}$ concentrations in both groups were $2.4 \pm 0.4 \mathrm{nmol} / \mathrm{L}$ and mean $\mathrm{T}_{4}$ concentrations in both groups were $53 \pm 7 \mathrm{nmol} / \mathrm{L}$ before injections of TRH. Plasma concentrations increased $(P<0.001)$ continuously to $4.8 \pm 0.3 \mathrm{nmol} / \mathrm{L}$ for $\mathrm{T}_{3}$ and to $153 \pm 15$ $\mathrm{nmol} / \mathrm{L}$ for $\mathrm{T}_{4}$ from 1 to $5 \mathrm{~h}$ after TRH administration, but there were no significant group differences.

\section{DISCUSSION}

\section{Feeding and Growth Performance}

This experiment was performed to investigate how much $\mathrm{C}$ and milk calves would ingest if $\mathrm{C}$ and milk were available ad libitum, but limited in maximal meal size (1.5 L), and to compare the effects of different milk consumption on feed efficiency, growth performance, and associated metabolic and endocrine traits. These studies were performed using an automated feeding system to ensure that calves fed unlimited amounts of milk were able to drink by their own decision (GrAL). Control calves were fed limited amounts of $\mathrm{C}$ and milk by automate. The amounts offered to control calves were comparable to those generally given in Swiss dairy farms (Egger and Kessler, 1994). Experiments in which calves were fed different amounts of $\mathrm{C}$ and milk by an automate starting on d 2 postpartum, and combined with studies to evaluate metabolic and endocrine status, have, to the best of our knowledge, not yet been performed.

Body weight increased in both groups during the first week of life, in accordance with studies in calves fed restricted amounts by automate (Steinhardt and Thielscher, 2000) and in neonatal calves suckling their dams (Egli and Blum, 1998). This was in contrast to calves fed restricted amounts twice daily by bucket, where no significant BW gain was measured during the first week of life (Hammon and Blum, 1998; Rauprich et al., 2000b). The BW gain in the first week of life was significantly higher in GrAL than in GrRS, but feeding efficiency did not differ between groups. However, during the 28-d period BW gain was only numerically higher in GrAL than in GrRS, although DMI was much higher in GrAL than GrRS. Therefore, feeding efficiency became numerically lower in GrAL than GrRS. Gallasz et al. (1973) found reduced feed utilization in older veal calves fed ad libitum by an automate compared with restrictively fed calves. Generally, feeding efficiency is relatively high, especially during the first week when compared to older calves (Terosky et al., 1997). This might be due to the absorption of high amounts of protein (Ig) during the first week of life by calves. As seen for GrAL, feeding efficiency decreased during the 28-d period and was in the range reported for veal calves in Switzerland (Gallasz et al., 1973; Hostettler-Allen et al., 1994; Hugi et al., 1997a). The high 
feeding efficiency, however, may also be a consequence of the automatic feeding system, which allows a more balanced nutrient intake and a better nutrient utilization, as seen with automatically fed veal calves (Kaufhold et al., 2000).

Maximal feed intake in GrAL was already reached on d 4, and then remained stable. From d 4 to 15, GrAL calves ingested almost twice as much as GrRS calves, clearly showing that calves with free access to milk ingest much higher quantities of food than is usually offered, in accordance with Bar-Peled et al. (1997) and Senn et al. (2000). With $11 \mathrm{~kg}$ of milk/d, calves in the first $2 \mathrm{wk}$ of life ingested in the range of 10 to $16 \mathrm{~kg}$, measured in automatically fed veal calves weighing 60 to $165 \mathrm{~kg}$ (Gallasz et al., 1973; Senn et al., 2000; Wyss, 1989). Intakes over $24 \mathrm{~h}$ were generally higher in GrAL than in GrRS from d 4 to 6, as expected. However, differences in intakes between groups on d 9 to 11 from 0800 to $2400 \mathrm{~h}$ were smaller because programmed intakes of GrRS increased, but were stable in GrAL. Intakes were higher in GrAL than in GrRS only from 2400 to $0800 \mathrm{~h}$, when calves of GrRS had ingested all their assigned milk.

The number of total visits to the automate (i.e., visits with [successful] and without [unsuccessful] milk intake, was greater in GrRS than in GrAL during the 10$\mathrm{d}$ observation period. Although the frequency of visits with milk intake was in the same range in both groups, the number of visits without milk intake was much greater in GrRS than in GrAL and this may have resulted in a greater rate of nonnutritive sucking at the nipple of the automate in GrRS. Nonnutritive sucking was seen more frequently in calves raised for potential breeding compared to veal calves, which received higher amounts of milk (Bolliger, 1998), indicating that the amount of ingested feed at least in part influences nonnutritive sucking. In this study, the amount of ingested feed similarly affected the frequency of nonnutritive sucking (i. e., restricted-fed calves showed enhanced nonnutrive sucking), indicating that the degree of satiety after milk intake had an influence on nonnutritive sucking. Nonnutritive sucking mainly occurs after milk intake (de Passillé and Rushen, 1997). However, the greater number of visits without milk intake in GrRS than in GrAL in our study may indicate that nonnutritive sucking also occurs without a connection to milk intake.

Meal size was small compared with amounts ingested by 5 -wk-old calves (Senn et al., 2000) because milk intake per visit was limited to maximally $1.5 \mathrm{~L}$ in both groups to avoid overloading the abomasum (Nickel et al., 1982). Mean total visits at the automate during 24$\mathrm{h}$ periods were greater in GrRS than in GrAL, whereas there were only slightly more frequent successful visits from 0800 to $2400 \mathrm{~h}$ in GrRS than in GrAL due to experimental conditions. As a consequence of higher milk intake, but not more successful visits per day in GrAL, meal size per successful visit was almost double that in GrAL than in GrRS. The records of the automatic feeder indicated that calves of GrRS frequently visited the automate during the night (2400 to $0800 \mathrm{~h}$ ), although without receiving feed. In short, these data clearly indicate that, as a consequence of limited feeding, calves of GrRS obviously never reached full satiety and therefore visited the automatic feeder more frequently than calves of GrAL.

\section{Hematocrit and Metabolic Traits}

Hematocrits decreased during the first month of life in accordance with previous studies (Egli and Blum, 1998; Hadorn et al., 1997; Rauprich et al., 2000a,b), probably as a consequence of hemodilution after first feed intake.

Total protein and IgG concentrations similarly increased after first feed intake in both groups due to absorption of colostral IgG, as expected. Concentrations of protein and IgG were similar in both groups during the first week of life and did not indicate a greater protein and IgG intake in GrAL than in GrRS. This was in contrast to Rauprich et al. (2000b), where greater protein and IgG intake with first $\mathrm{C}$ enhanced plasma IgG concentrations in neonatal calves. In contrast, the higher feeding level influenced plasma albumin concentrations during the experimental period.

The marked rise of plasma urea concentrations from birth to d 3 possibly mirrored higher rates of protein degradation or AA deamination after high protein intake. It was unlikely to result from renal dysfunction because creatinine concentrations were in the normal range (Hadorn et al., 1997; Kühne et al., 2000; Rauprich et al., 2000a,b). Surprisingly, higher protein intake in GrAL than in GrRS did not affect urea concentrations. This was in contrast to neonatal calves fed C twice daily by bucket, which had elevated urea concentrations on d 3 and 7 (Rauprich et al., 2000b).

Glucose concentrations at birth were low and increased after feed intake, as shown in other studies on C-fed calves (Hadorn et al., 1997; Hammon and Blum, 1998; Rauprich et al., 2000b). Higher feeding intensity in GrAL than in GrRS did not affect plasma glucose concentrations, indicating that glucose homeostasis was maintained. Lactate concentrations typically decreased in the first week of life, as seen in previous studies (Hadorn et al., 1997; Hammon and Blum, 1998; Rauprich et al., 2000b), but were not influenced by differences in feeding intensity. 
Plasma NEFA concentrations decreased much more in GrAL than in GrRS from birth to d 3 and were lower in calves with unlimited feed intake, indicating a greater inhibition of fat mobilization with higher feeding intensity. Triglyceride concentrations in neonatal calves are influenced by fat absorption and especially by time point and amount of ingested $\mathrm{C}$ (Blum et al., 1997; Hammon and Blum, 1998; Rauprich et al., 2000b). Concentrations increased in both groups in the present study, but were not affected by feeding intensity, even though fat intake was much higher in GrAL than in GrRS. This was in contrast to previous findings, which showed that additional $\mathrm{C}$ feeding in bucket-fed calves increased triglyceride concentrations (Kühne et al., 2000; Rauprich et al., 2000b). The increase of cholesterol concentrations during the first month of life was typical (Leat, 1967) and reflected the dependence on early ingestion of C (Blum et al., 1997; Egli and Blum, 1998; Hammon and Blum, 1998). However, the higher feeding intensity in GrAL vs GrRS did not influence cholesterol concentrations during the first 3 wk of life, and even resulted in lower cholesterol concentrations on $\mathrm{d} 28$. This was in marked contrast to previous studies that showed higher cholesterol concentrations in intensively C-fed calves during first week of life (Hammon and Blum, 1998; Kühne et al., 2000; Rauprich et al., 2000b) and in suckling calves (Egli and Blum, 1998).

\section{Endocrine Traits}

Insulin concentrations in GrAL were higher in the 28d period than in GrRS. Plasma insulin concentrations depend on amounts of ingested C (Hammon and Blum, 1998; Kühne et al., 2000; Rauprich et al., 2000a,b) as well as on the amount of ingested energy intake (Hugi et al., 1997b), a finding supported by the present study. Plasma glucagon concentrations increased after $\mathrm{C}$ intake, in accordance with previous studies (Hammon and Blum, 1998; Kühne et al., 2000; Rauprich et al., $2000 a, b)$. Glucagon is known to stimulate gluconeogenesis, which is very important for glucose homeostasis after birth (Girard, 1986). Glucagon concentrations in calves with free access to $\mathrm{C}$ during the first $3 \mathrm{~d}$ did not differ from glucagon concentrations in restricted C-fed calves. This was in contrast to elevated glucagon concentrations in calves fed different amounts of $\mathrm{C}$ twice daily by bucket during the first $3 \mathrm{~d}$ of life (Rauprich et al., 2000b). Low glucagon concentrations on $d 7$ of life in the present study were also found in calves fed by bucket (Hammon and Blum, 1998; Rauprich et al., 2000b).

Cortisol concentrations after birth decreased during the first week of life, as shown repeatedly in neonatal calves fed by bucket (Hadorn et al., 1997; Hammon and
Blum, 1998; Rauprich et al., 2000a,b). The decrease was more pronounced in calves with unlimited feed intake, apparently reflecting greater nutrient intake after birth. Cortisol is part of the glucoregulatory endocrine system and may stimulate gluconeogenesis in neonatal liver. Reduced $\mathrm{C}$ intake in calves fed twice daily by bucket is associated with elevated plasma cortisol concentrations (Hammon and Blum, 1998; Rauprich et al., 2000a).

The somatotropic axis is basically functioning in neonatal calves, but has not reached full maturity (Blum and Hammon, 2000; Hammon and Blum, 1997). Thus, plasma GH concentrations rapidly increased in response to GRF administration in both groups and, continuously decreased after GRF administration thereafter, as shown previously (Hammon and Blum, 1997). Plasma GH concentrations showed no group differences and did not change in a consistent manner during the experimental period, although nutrient intake differed markedly between groups. That GH responses to differences in feed intake are small, was previously described in neonatal calves (Baumrucker and Blum, 1994; Grütter and Blum, 1991; Hammon and Blum, 1997).

Colostrum supply affects IGF-I plasma concentrations in neonatal calves by stimulation of IGF-I expression in the liver (Cordano et al., 2000), whereas colostral IGF-I has local effects in the gastrointestinal tract, but no systemic effects in neonatal calves (Baumrucker et al., 1994; Hammon and Blum, 1997; Vacher et al., 1995). In the present study, IGF-I concentrations decreased during the first week of life, followed by an increase up to d 28 in both groups, as shown in calves fed twice daily by bucket (Hammon and Blum, 1997; Hostettler-Allen et al., 1994; Kerr et al., 1991). The nutrient supply affects the somatotropic axis and IGFI status, elevates IGF-I levels, and enhances growth rate (Jones and Clemmons, 1995). Most surprisingly, greater DMI and BW gain in GrAL was associated with a trend to lower plasma IGF-I concentrations in GrAL than in GrRS. Calves fed enhanced amounts of C (and DMI) during the first week also did not show elevated plasma IGF-I concentrations on 7 compared to control calves fed less intensively (Rauprich et al., 2000b). However, calves fed a milk replacement instead of $\mathrm{C}$ showed reduced IGF-I plasma concentrations (Grütter and Blum, 1991; Hammon and Blum, 1997; Kühne et al., 2000). Thus, the IGF-I status in neonatal calves depends on the type of ingested feed, but seems not to be improved by maximizing $\mathrm{C}$ intake and DMI.

Concentrations of $\mathrm{T}_{3}$ and $\mathrm{T}_{4}$ were typically high at birth and then decreased to relatively low levels on $\mathrm{d}$ 7 and remained low, as shown in previous studies (Egli and Blum, 1998; Hadorn et al., 1997; Hammon and Blum, 1998). Concentrations were in the physiological 
range and were not influenced by different feeding intensities, as shown previously (Hadorn et al., 1997). This was also supported by TRH administration on d 8 because $\mathrm{T}_{3}$ and $\mathrm{T}_{4}$ concentrations did not differ between the groups fed at different intensities.

In conclusion, calves with free access to feed ingested a markedly greater quantity of food than is usually offered with the traditional restrictive feeding plans, and maximal amounts of feed intake in calves with unlimited feed intake was reached already on $\mathrm{d} 4$. Calves with free access to $\mathrm{C}$ and milk were able to digest and metabolize high amounts of feed even during the first week of life. Calves with free access to $\mathrm{C}$ and milk did not differ markedly with respect to successful visits at the automatic feeder, but their meal sizes per visit were greater. Higher feed intake was reflected by a higher BW gain in the first week, but not up to $\mathrm{d} 28$. Differences in blood plasma metabolite and hormone concentrations were rare. Calves with unlimited feed intake had low plasma concentraions of NEFA and cortisol and higher insulin concentrations, but, surprisingly, showed a trend toward lower IGF-I plasma concentrations.

\section{ACKNOWLEDGMENTS}

We would like to thank Y. Zbinden, C. Morel, and C. Philipona (Division of Nutritional Pathology, Faculty of Veterinary Medicine, University of Berne, Switzerland) for their excellent laboratory work. Many thanks also to H. Schnyder, J. Sturny, and E. Lehmann at the Swiss Federal Research Station for Animal Production, Posieux, Switzerland, for putting the calves at our disposal and for technical support regarding the automatic feeder. We thank UFA AG (Sursee, Switzerland) for placing the automatic feeders at our disposal.

\section{REFERENCES}

Bar-Peled, U., B. Robinzon, E. Maltz, H. Tagari, Y. Folman, I. Bruckental, H. Voet, H. Gacitua, and A. R. Lehrer. 1997. Increased weight gain and effects on production parameters of Holstein heifer calves that were allowed to suckle from birth to six weeks of age. J. Dairy Sci. 80:2523-2528.

Baumrucker, C. R., and J. W. Blum. 1994. Effects of dietary recombinant human insulin-like growth factor-I on concentrations of hormones and growth factors in the blood of newborn calves. J. Endocrinol. 140:15-21.

Baumrucker, C. R., D. L. Hadsell, and J. W. Blum. 1994. Effects of dietary insulin-like growth factor I on growth and insulin-like growth factor receptors in neonatal calf intestine. J. Anim. Sci. 72:428-433.

Blum, J. W., U. Hadorn, H.-P. Sallmann, and W. Schuep. 1997. Delaying colostrum intake by one day impairs plasma lipid, essential fatty acid, carotene, retinol and $\alpha$-tocopherol status in neonatal calves. J. Nutr. 127:2024-2029.

Blum, J. W., and H. Hammon. 2000. Colostrum effects on the gastrointestinal tract, and on nutritional, endocrine and metabolic parameters in neonatal calves. Livest. Prod. Sci. 66:151-159.
Bolliger, T. 1998. Modell zur Steuerung des Saugverhaltens bei Kälbern. Diploma Work, Univ. Zürich, Zürich, Switzerland.

Breier, B. H., and H. Sauerwein. 1995. Regulation of growth in ruminants by the somatotropic axis. Pages 451-474 in Ruminant Physiology: Digestion, Metabolism, Growth and Reproduction. W. von Engelhardt, S. Leonhard-Marek, G. Breves, and D. Giesecke, ed. F. Enke Verlag, Stuttgart, Germany.

Cordano, P., H. M. Hammon, C. Morel, A. Zurbriggen, and J. W. Blum. 2000. mRNA of insulin-like growth factor (IGF) quantification and presence of IGF binding proteins, and receptors for growth hormone, IGF-I and insulin, determined by reverse transcribed polymerase chain reaction, in the liver of growing and mature male cattle. Domest. Anim. Endocrinol. 19:191-208.

De Passillé, A. M., and J. Rushen. 1997. Motivational and physiological analysis of the causes and consequences of non-nutritive sucking by calves. Appl. Anim. Behav. Sci. 53:15-31.

Egger, I., and J. Kessler. 1994. Fütterungsempfehlungen für das Aufzuchtkalb. Pages 51-68 in Eidgenössische Forschungsanstalt für viehwirtschaftliche Produktion, ed. Fütterungsempfehlungen und Nährwerttabellen für Wiederkäuer. Landwirtschaftliche Lehrmittelzentrale, Zollikofen, Switzerland.

Egli, C. P., and J. W. Blum. 1998. Clinical, haematological, metabolic and endocrine traits during the first three months of life of suckling Simmentaler calves held in a cow-calf operation. J. Vet. Med. A 45:99-118.

Erhard, M. H., U. Lösch, and M. Stangassinger. 1995. Untersuchungen zur intestinalen Absorption von homologem und heterologem Immunglobulin G bei neugeborenen Kälbern. Z. Ernaehrswiss. 34:160-163.

Gallasz E., F. Jans, and H. Schneeberger. 1973. Fütterungstechnische Betrachtungen zur Verwendung von Tränkeautomaten in der Kälbermast und Kälberaufzucht. Mitteilungen für die Schweizerische Landwirtschaft, Nr.7, Jahrgang 21.

Girard J. 1986. Gluconeogenesis in late fetal and early neonatal life. Biol. Neonate 50:237-258.

Graf, B., N. Verhagen, and H. H. Sambraus. 1989. Reduzierung des Ersatzsaugens bei künstlich aufgezogenen Kälbern durch Fixation nach dem Tränken oder Verlängerung der Saugzeit. Züchtkde. 61:384-400.

Grütter R., and J. W. Blum. 1991. Insulin-like growth factor I in neonatal calves fed colostrum or whole milk and injected with growth hormone. J. Anim. Physiol. Anim. Nutr. 66:231-239.

Hadorn, U., H. Hammon, R. M. Bruckmaier, and J. W. Blum. 1997. Delaying colostrum intake by one day has important effects on metabolic traits and on gastrointestinal and metabolic hormones in neonatal calves. J. Nutr. 127:2011-2023.

Hammon, H., and J. W. Blum. 1997. The somatotropic axis in neonatal calves can be modulated by nutrition, growth hormone, and Long$R^{3}$-IGF-I. Am. J. Physiol. 273:E130-E138.

Hammon, H. M., and J. W. Blum. 1998. Metabolic and endocrine traits of neonatal calves are influenced by feeding colostrum for different durations or only milk replacer. J. Nutr. 128:624-632.

Hostettler-Allen, R., L. Tappy, and J. W. Blum. 1994. Insulin resistance, hyperglycemia, and glucosuria in intensively milk-fed calves. J. Anim. Sci. 72:160-173.

Hugi, D., R. M. Bruckmaier, and J. W. Blum. 1997a. Insulin resistance, hyperglycemia, glucosuria, and galactosuria in intensively milk-fed calves: Dependency on age and effects of high lactose intake. J. Anim. Sci. 75:469-482.

Hugi, D., S. H. Gut, and J. W. Blum. 1997b. Blood metabolites and hormones-especially glucose and insulin-in veal calves: effects of age and nutrition. J. Vet. Med. A:407-416. Jones J. I. and D. R. Clemmons. 1995. Insulin-like growth factors and their binding proteins. Biological actions. Endocr. Rev. 16:3-34.

Kaufhold, J. N., H. M. Hammon, R. M. Bruckmaier, B. H. Breier, and J. W. Blum. 2000. Postprandial metabolism and endocrine status in veal calves fed at different feeding frequencies. J. Dairy Sci. 83:2480-2490.

Kerr, D. E., B Laarveld, M. I. Fehr, and J. G. Manns. 1991. Profiles of serum IGF-I concentrations in calves from birth to 18 months of age and in cows throughout the lactation cycle. Can. J. Anim. Sci. 71:695-705. 
Kirchgessner, M. 1996. Tierernährung. 9th ed. DLG-Verlag, Frankfurt (Main), Germany.

Kühne, S., H. M. Hammon, R. M. Bruckmaier, C. Morel, Y. Zbinden, and J. W. Blum. 2000. Growth performance, metabolic and endocrine traits, and absorptive capacity in neonatal calves fed either colostrum or milk replacer at two levels. J. Anim. Sci. 78:609-620.

Leat, W. M. F. 1967. Plasma lipids of newborn and adult ruminants and of lambs from birth to weaning. J. Agric. Sci. 69:241-246.

Merriam, G. R., and K. W. Wachter. 1982. Algorithms for the study of episodic hormone secretion. Am. J. Physiol. 243:E310-E318.

Meyer, H., and J. Kamphues. 1990. Grundlagen der Ernährung von Neugeborenen. Pages 55-71 in K. Walser and H. Bostedt, ed. Neugeborenen und Säuglingskunde der Tiere. Enke Verlag, Stuttgart, Germany.

Nickel R., A. Schummer, and E. Seiferle. 1982. Page 149 in Lehrbuch der Anatomie der Haustiere, Bd. II. 5th ed.Verlag Paul Parey, Berlin and Hamburg.

Odde, K. G., G. H. Kiracofe, and R. R. Schallers. 1985. Suckling behavior in range beef calves. J. Anim. Sci. 61:307-309.

Rauprich, A. B. E., H. M. Hammon, and J. W. Blum. 2000a. Effects of feeding colostrum and a formula with nutrient contents as colostrum on growth performance, health status, and metabolic and endocrine traits in neonatal calves. Biol. Neonate. 78:53-64.
Rauprich, A. B. E., H. M. Hammon, and J. W. Blum. 2000b. Influence of feeding different amounts of first colostrum on metabolic, endocrine, and health status, and on growth performance in neonatal calves. J. Anim. Sci. 78:896-908.

Riese G., G. Klee, and H. H. Sambraus. 1977. Das Verhalten von Kälbern in verschiedenen Haltungsformen. Dtsch. Tieraerztl. Wochenschr. 84:388-394.

SAS User's Guide: Statistics, Version 6.11 Edition. 1994. SAS Inst., Inc., Cary, NC.

Senn, M., S. Gross-Lüem, H. Leuenberger, and W. Langhans. 2000. Physiol. Behav. 70:189-195.

Steinhardt, M., and H.-H. Thielscher. 2000. Tiergerechte Haltung und physiologische Funktionen von Tieren. Tieraerztl. Umschau $55: 189-198$

Terosky, T. L., A. J. Heinrichs, and L. L. Wilson. 1997. A comparison of milk protein sources in diets of calves up to eight weeks of age. J. Dairy Sci. 80:2977-2983.

Vacher, P.-Y., G. Bestetti, and J. W. Blum. 1995. Insulin-like growth factor I absorption in the jejunum of neonatal calves. Biol. Neonate. 68:354-367.

Wyss, U. 1989. Der Einsatz von Vollmilch in der Kälbermast. Die Grüne 38:22-23. 